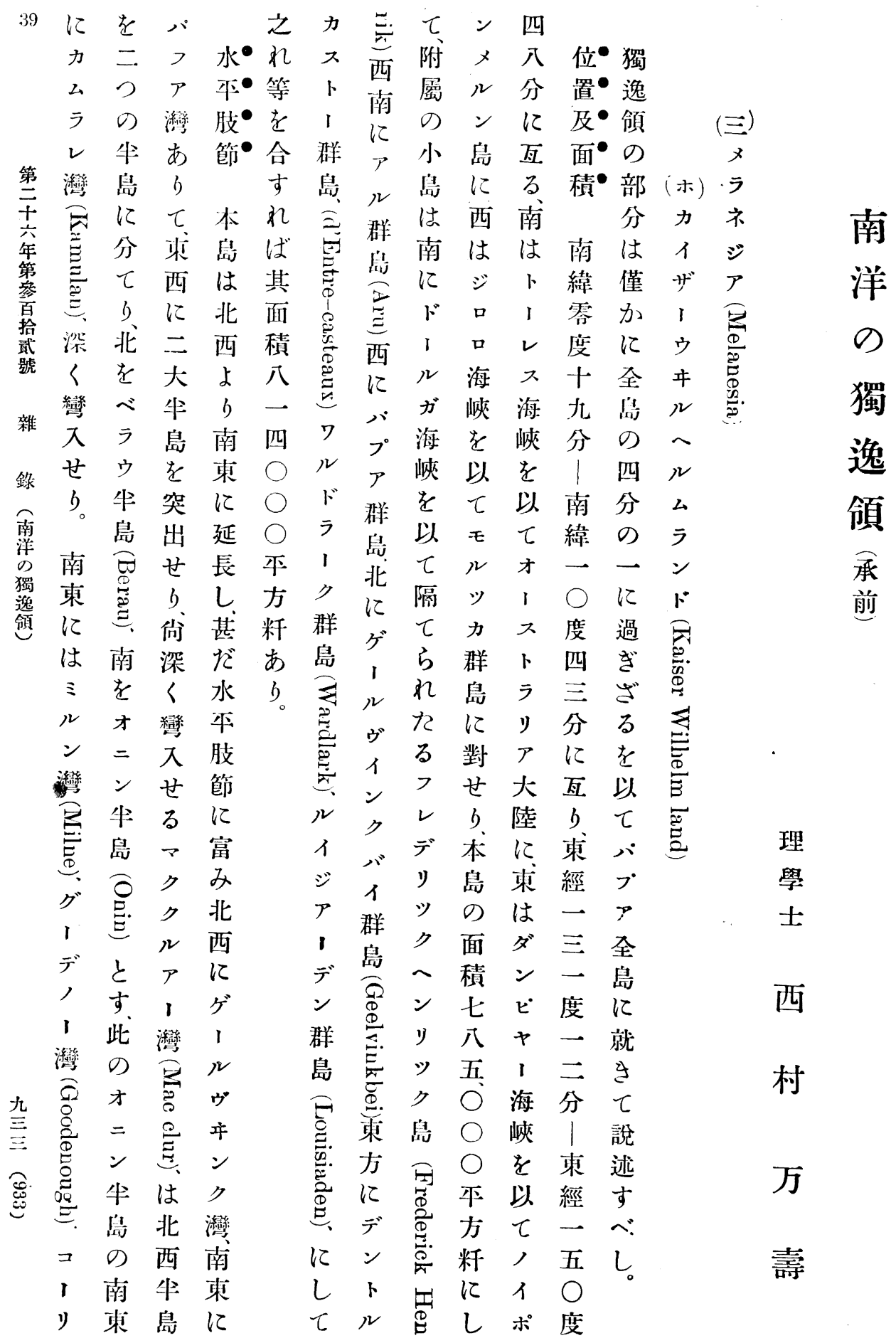




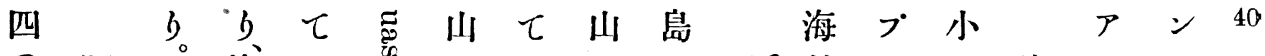

○獨 海オ脈ヴはの地・帮の本海スグ

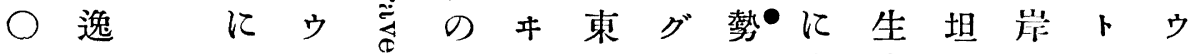

○領入爷西》方, 大㕕のは口!

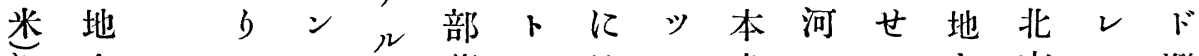

に方てスバ蘭ル連木島のるあ東、灣第

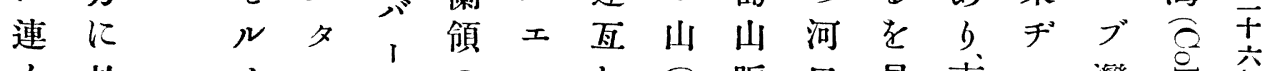

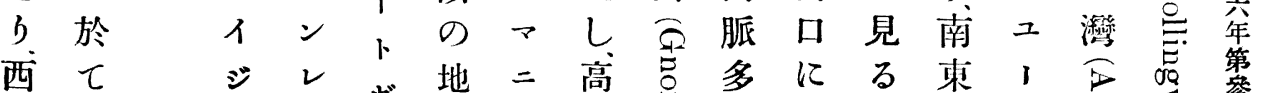

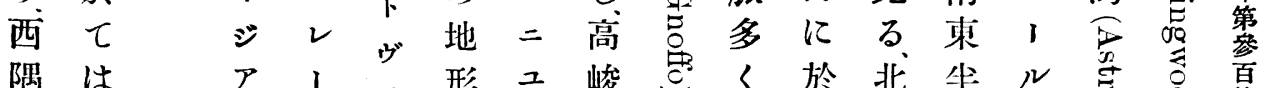

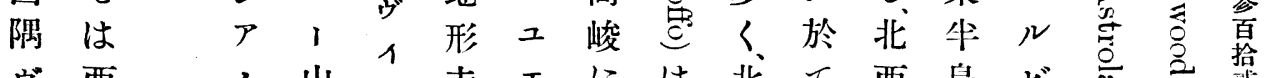
ヴ西、山ク未ェには北て西島ビ总总鸽

イに $゙$ 脈、だルし最西は牛のル焉ダ

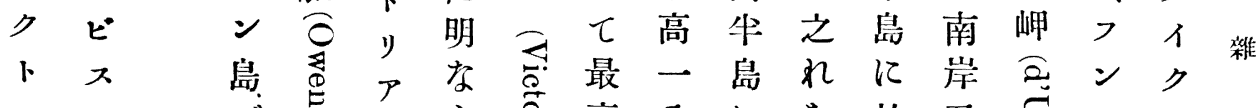

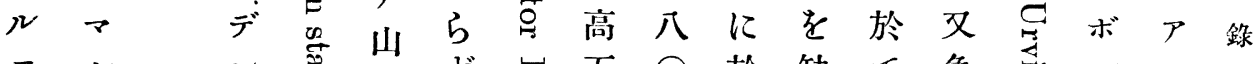

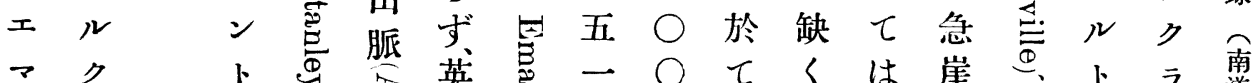

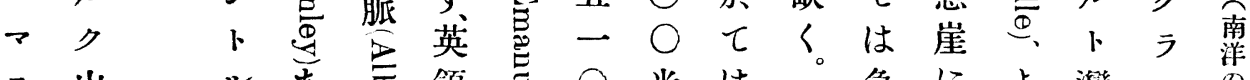

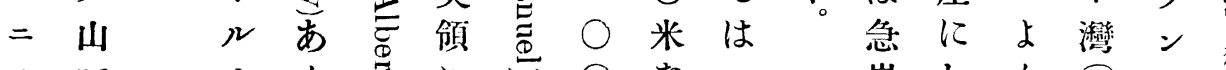

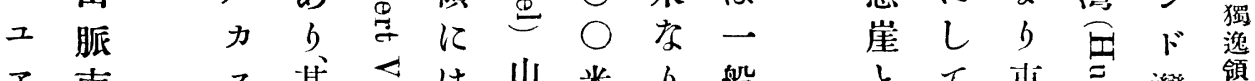



ル東、最总獨脈の土に

山1 1 高 領亦 ス卜山

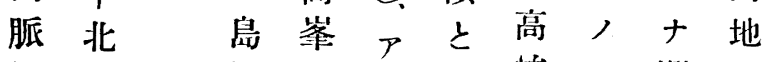

に西、にヴルの峻、灣に

連に 入イバ境につ頭し

る。走 只ク

之

れ北 $\bigcirc$ 山近严テけラ



の八正山脈東 $○$ ㇒半

諸ン至は至に○秀i島

山㟔一四兽走乃峯レ最

はン $○ ○$ よ



万公南么六英人七

季㝕米米東入 $\bigcirc$ 猲 ス四



に兰高秀島レ米の 兰

は $\overrightarrow{0}$ 距等を、党密才

雪 0 をを横 ブ 、界恋二

( 保な斷山此に占之

以 1

ししし脈の於兽牛

平 胴 岬

地體

互南氖等宫

に岸にり。

擴は至。元

が低る 小

b平間灣

四なは市

周る一b

現 砂 般

瑚 地に

礁に急

多し 崖

ᄂ $\tau$ に

南處し

西名て

$P>$ 其

レン 間

フグ諸

北

I 口處

部

に

は

低 
北氷文あ本入る口不長司に本本山被

北各り、島の \&千ク垁注島島脈は

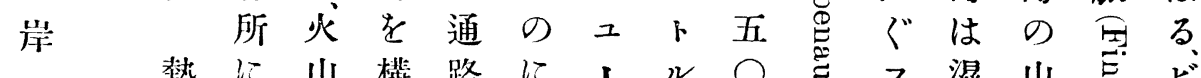







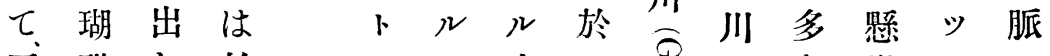

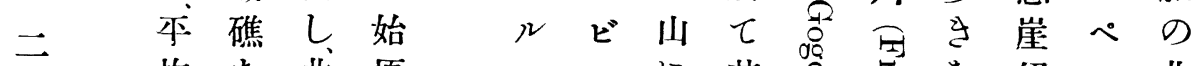

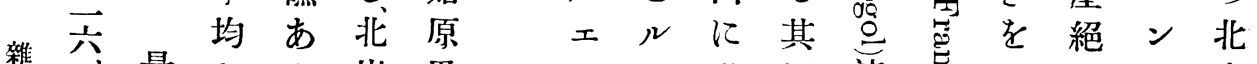

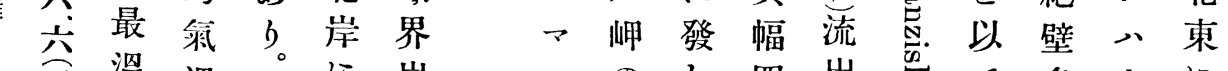

錄亥 溫溫。の岩

月月の沿石 の

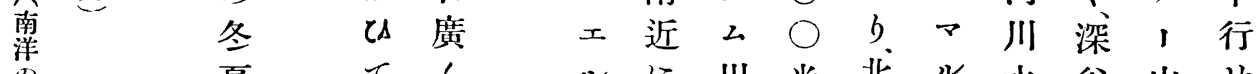

獨夏てく水に米北ル水谷山世



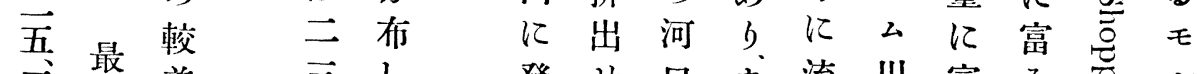

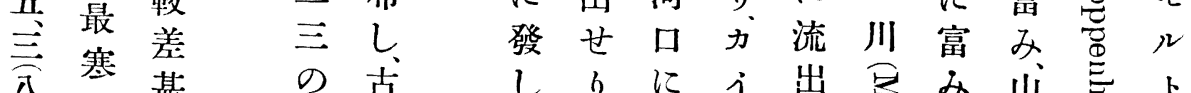

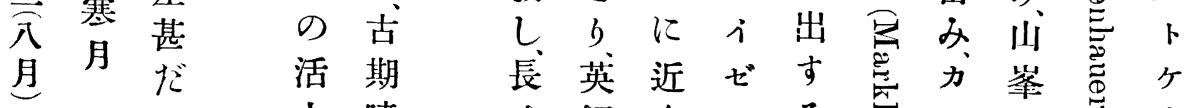



な山出 八に流アラ苞ゼ立は脈

く 岩 $\bigcirc$ 於出ウム流ル裸實

三最

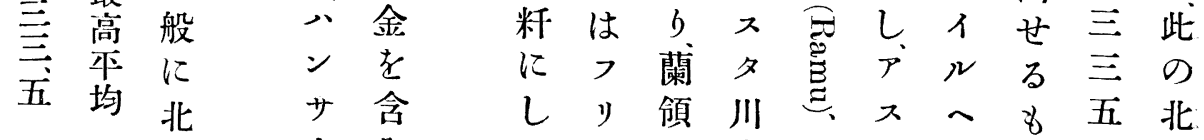



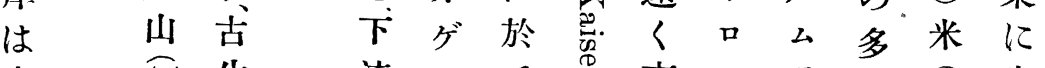

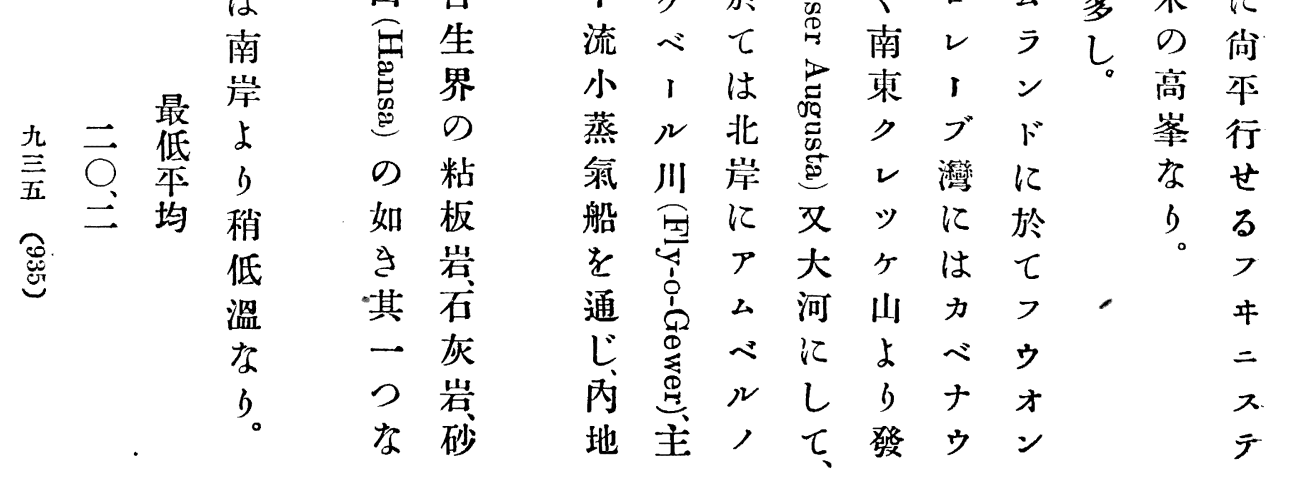


のて 空育岸せ气ててジリしは



のの多植內 丙物とを气五デ、シ北西厴南

多少少物地了、云は○りリ二部季は岸

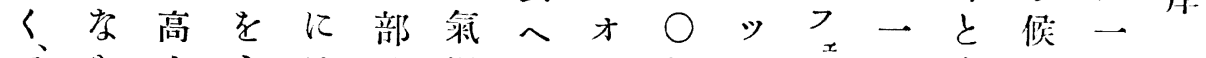

发学山主は分溫b、粍只五南風般

固南植と熱はの・ェのウ二ののあに一军

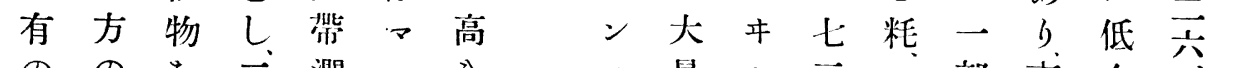

ののを三濶ンを量ル三主部南く尤

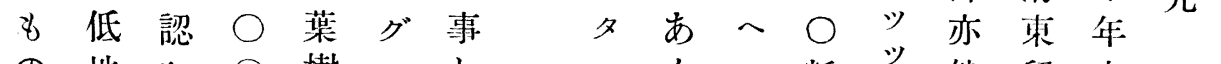

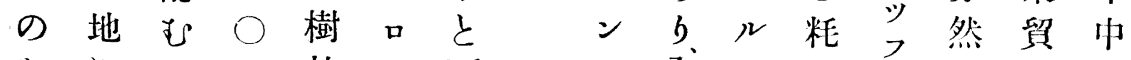



有於乙米繁

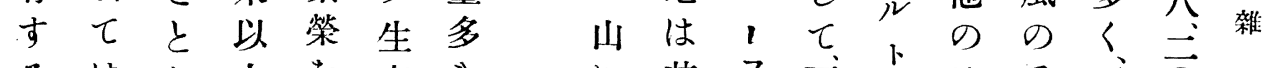

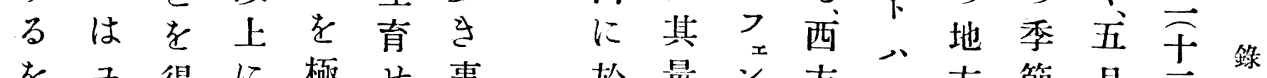

を工得に極女事於量シ方方方節月云錄

以ウ。はめ 只と て

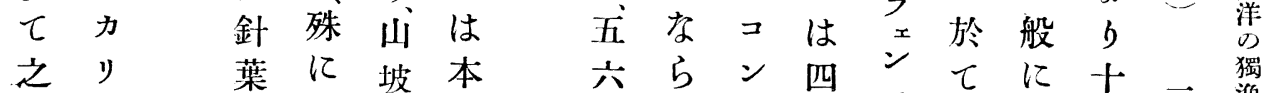

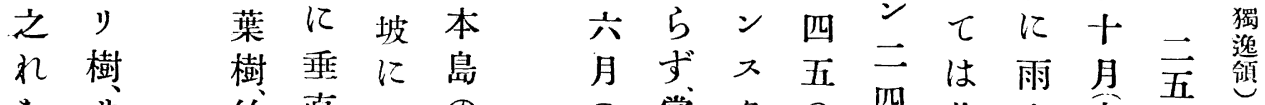

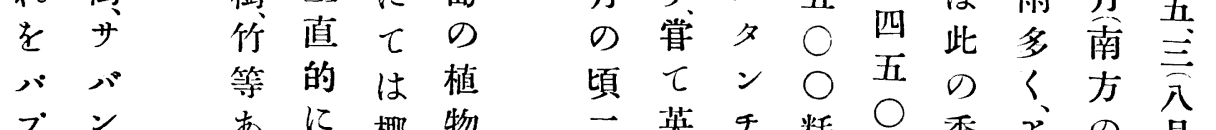

ブン あに梛物 三英チ粍 㘪季宁の合

アナ 3 は子 $の$

區あ て九樹生

と 与羊 ○灌育

す以菌 ○本を

南上 植 米寄 盛

方植物 | 生 $九$

は物蘚一植な

才界。苔 ○物 ら

小を類 $\bigcirc$ 空 $し$

入通を

呵領 ン 以粍節

○ギ、上ざ雨卜它

$O=1 の$ 入少口は

| ア フ

六總と市

○督の古

○間低、せ女風

卜覽混米植 熱

米 $b$ の 地、

ラすずま物帶

リる 最で攀林

$ア に$ 高灌木繁

區 ズ の木植茂

にン、地羊物す。

屬名方齿南

す諸 に 植く北

る島想物發兩

の $>に>$ 雨 $>b$

高 $\checkmark$ は量ウ其

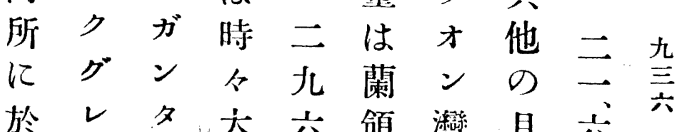

於レ夕大六領灣, 月、六

て ゴイ

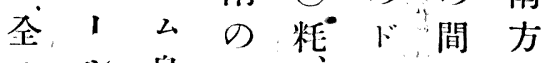

હ

$く ル$ 島地 $>$ 特の

乾㞯にあイとに夏

燥总於 b、ン八著沉 


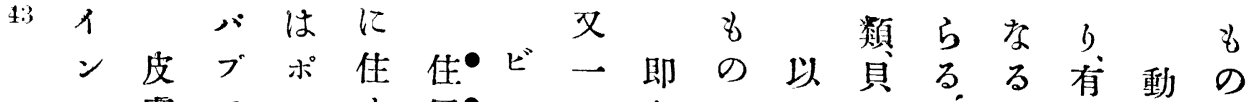

シ膚アリす民一少類昆狗袋物な

工の人ネる $、$ ○本り。動に䖪毛類界 。

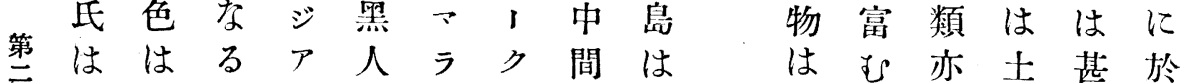



公の 色 の の の 語岛为勢颂多は



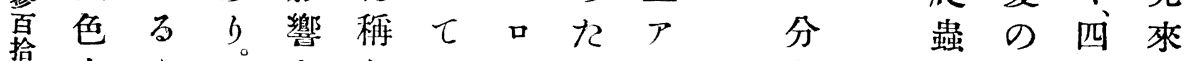

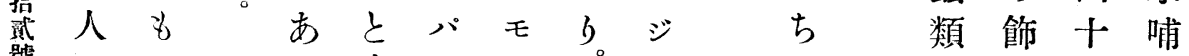

號ののるす、プ群。ア る 蛇種乳

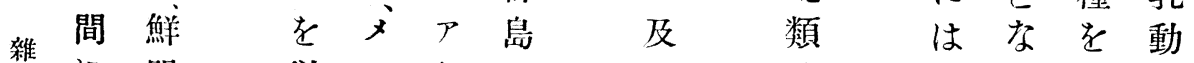

に 以 明 以

錄生な亲云生方東毒其す少

南れる 海 シ ふ物印艮皮べな



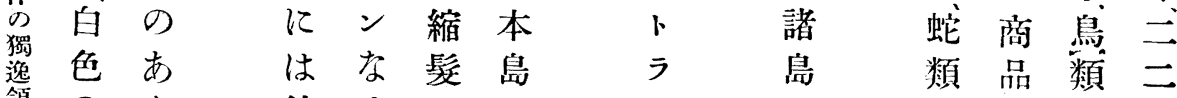

領の b、純る

子叒粹8 人同子

女多ののの多の奇虾る常齿

あ少 \& 之義。陸蝪㕛に類





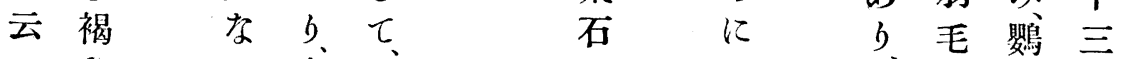

人色く、本二。の四字鵡種

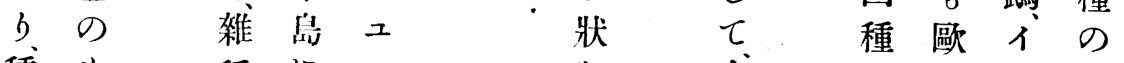

種为種に学有可人ン 蝙



はあるせ せ 類 類帽 カ 類

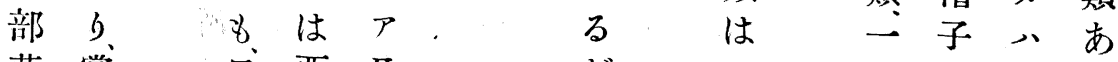

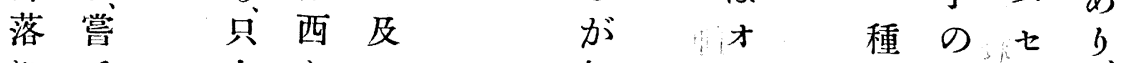

に出よび 如

九分本地 b 其解飾極に

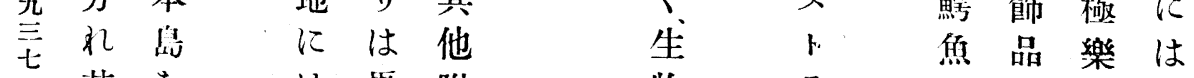



怘の探純 來近 界 リ



部世固南諸於特輸く、海

落し有束小浑小出其牛

のフ の に 帛

为 のの魚せ美市 


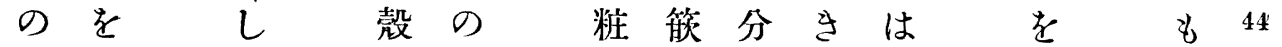
武用貧め飲を衣元飾插をて赤南な毛の 器 Us 富煙食燃服來多せ多兩色東し髯的 及金は草物燒を裸しるか煩顔の之は皮 赤屬其ははし着體。方らに料地れ始膚 色製携白パて沉のし亘を方を如第

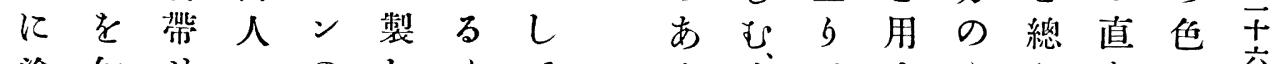




㕛ず粧る芭るあ、抹飾橫のはし し、名

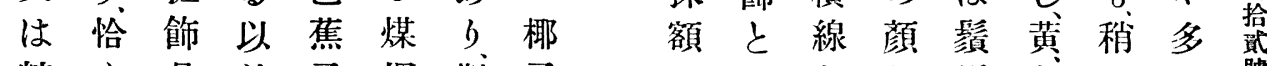

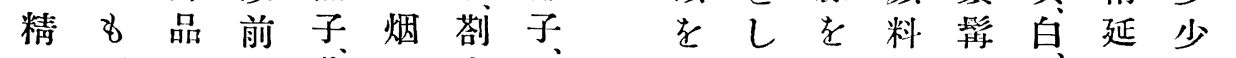
巧石によ薯を青 サ施て描のを赤び異

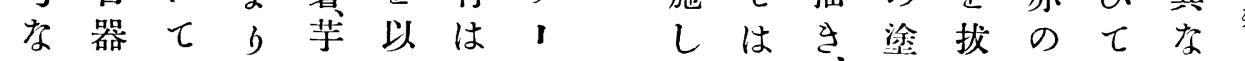
る 時知男等て多ゴ粧牙兩抹先顔縮れ釦 彫代る 女の 花く樹 刻の事之類饺施の を如をれををさ葉 施し得を客畫ぶを し弓家用とさる以

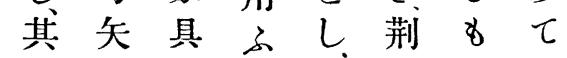
意はは嘗豚䊂皮衣 匠重木䉆学膚服 飾 貝眼は屡 料毛 b。 到等の種眉をと 万を周亦毛用学 ざ以園なををと

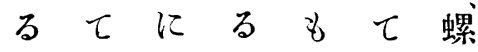
な腕白战拢之旋 く環色最学れ狀 世耳方去をに 見要製食鼠以儿界環環普与、染生 るなの人我て俩し、第頸を通皮め長

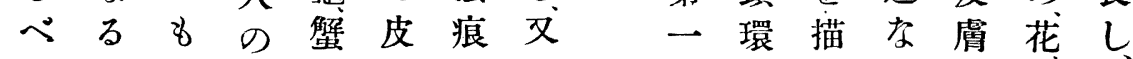


子器土市類を附腰粧施時多極毛當 のに製 $b$ 刺し部飾しに沉のめ仝の あしの九食すてを家发頸はて殼長

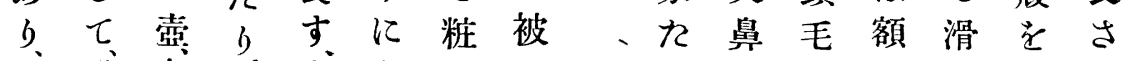
家矛蕧。炎あ飾へ。障を澤以に 具㭘床は の棍石栱せ专 彫 棒紊片苦 b の 刻楯貝を楚剳あ せを製磨知靑り る用牙擦るの今 ๖ゆ製しべ法 日 の此の て し は は 亦犯道生。楖歐 同等具 ぜ 子風 若を去りに至 马 穿 b 顎し之れ 男ちてに顏れば 子七 其向料を尖


女白粧一塗れ縮 子のす縱抹 的和


了牙骂多多 すを部描く塊

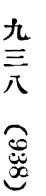


45 本 又五

袋

のb方をを㖇床口

じ

島來二沿・鼠生あてに穿航防存は四家土

のれ八鞀業 島 b 年 䒽は 航 置


性 二 北本內耕 第索六岸昆作 す之邊はる上又七形製

干る○には润に 窄事宍西一 U U 篦を年班五女て 萦明ル牙二子甘 㖪か人人六は藷 碞飞大ア年豚サ


雜 錄然入口牙愛 薯 れデリ人す芓 南 ど ド 洋む、サ泎を

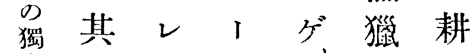
逸報入べデに作 告はドメ從し はルラネ事・男 秘 1來ビす子 密ジ 万石は にP $\therefore$ の せ 1 五發狩地 らデ四見獵を れン四せは開 れを年る少墾 与、發同處し。 一見國に。女

六し人 乙 子

$\bigcirc$ r $ル \tau$ 耕 五、合作 九 年 レ 芚ウ

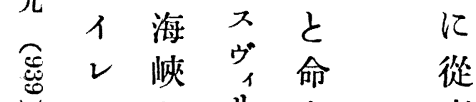
ンを 名事 ヤ通口索 す ン過、少 スしボ一豚
㕛れに一にのは米狀造 竹を一般あ生蒂奥はは 筏數二他 b活を行大 あ條枚の地艺敷四小伓

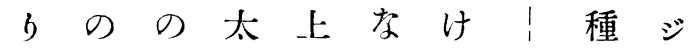
又横水平よしる一名! 楖 材板 洋 $b$ 今 子をを讙二日の米し島 葉以筷岛五少あにて、以 をて 插と! 原 り し 二 西 以舟し同三人>て般に てに之じ五のイ長にし 緊れく尺風ン方家て 狀結に獨と老 のせ彩木す存二尔はに 籠 b 畫舟 世八b、急は を多をを 马、棑傾之 作く施用发了子斜を 勺はせゆ樹シ葉に認 少一b、長上罢雜垂め 年種顛さ家吉草れず。 のに覆三 屋导に船 之し 豫 $\bigcirc$ を总て小 和防尺作导家屋 に時の乃 bに根の 乘に爲至 $\tau$ を 如 b 二長三生は葺く て種さ $○$ 活木先棟 里の十尺造竹梁 收餘宁四樹 る家をの のの五幹和屋編高 に海あ間ののあみさ 從を b 事航蒂 圆 央 す 帆材に 与杜壁 蓋 工 と六

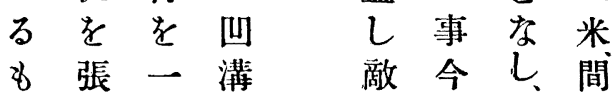





殖て獨・な $\bigcirc$ 蘭大時一夕基で十り 七 び 岸 民本逸れ $\bigcirc$ 領勢に月イ督西九。 地國領 b 本最力同六ン呚岸世 とプ砂方 \&に國日スの及紀

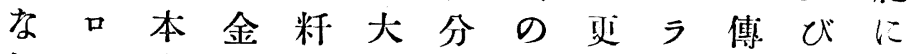
れイ芘探あに割有めン道北入

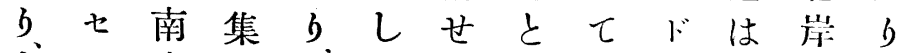
人ン東等二公て らな南の甚にて 口よ部の八其れれ東官だ傅二 はbに鐄八面九部吏入道八 ビ稍 位業八積 る。二を本り所二 ス小し、者年四。分保而薙及四

$\checkmark$ な力多九 $\bigcirc$

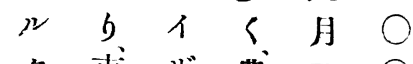
ク東ザ農四 0 群方、耕日 島に户充直 $\bigcirc$ を配市分轄平 合列 2 殖方 しすへ 方民䊀 てるルず地餘 土ビム。をな 人スラ杏る 五

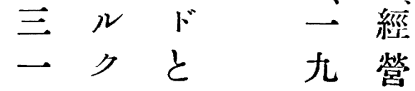

○群 稱

0 島 $L$

○ 其 あ步面

·与、積 白一一 人八刀

二 九 二

八九 0

三年 0

人四 0

中月本

二一方

六 日 䊅

四直に $\bigcirc$ 充

五分

年 极

才

1 ず

又英

卜 领

ラ 之

リれ

ア に

聯 次

邦ぎ

の 二

$\rightarrow$ 二

州九
八護束かび年

五地部了滴八

年とにし舘 月

蘭索來がを二

獨世名同建十

間 $b$, 英敎 $\tau$ 四

に次國は同日

一での西國和

八北所部艦、蘭

八東領に榢の

六部を廣來保

年に定く航護

獨獨め傳 せ地

英逸九はb と

間國与行二な

《旗しb公b

境揭が之八南

界揚本礼五岸

劃せ國よ年に

定 ら政 b佛ド

せれ府前人 I

らビ之一桃ブ

れスれ八不

爱子を八罂港

にル認三人在

本, め年亦䦌

晶群ず四來、

歐炛翌月れ九

の亦年四 b
年 附 東

ゼ近方

のに

厶 品 航

スをせ竹

ク訪 b、篦

\% es - 䔔

ク六

世 b -

界一六

老年

週六ウ 錄

航二才

し 年夕南

再英 ! 总

び人ジ獨

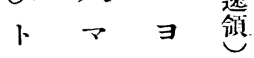

$\mathrm{I}=\mathrm{I}$

ᄂ

万䘮 ン

海 征 桃

峽 服 b

t

通て 六

航 始 九

し 九

て 年

始卜

女) 1 年

$\tau<y$

其 $ᄌ P$

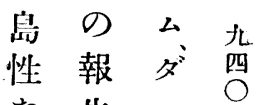

な告 ン

万老 ピ

事發

光

明 ᄂ 北 
47 灰 $\sim$ の

岩ン地・小に位・金財信 $、$ ス 一五コは



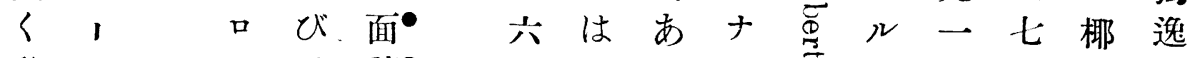
發ラノンて 皘・五少り。イ宫ク二二子、人

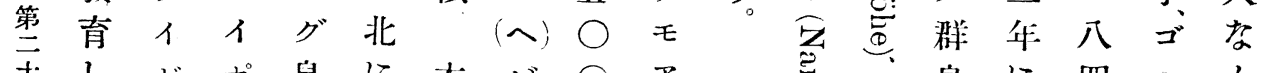



窑火灣ン

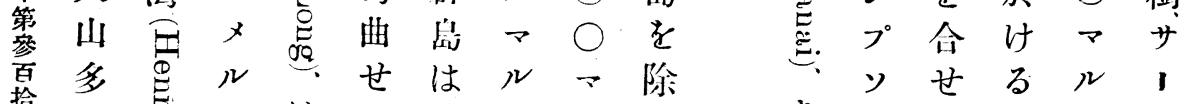

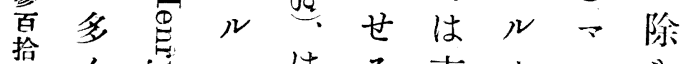



號 北芭帛本群緯群ク他



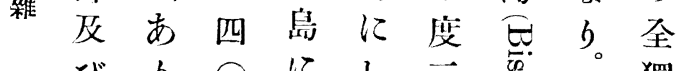

錄 び



南部間本ガ總分窃領



獨配八䉼グ皘南导於



し、の 鸟 七六

$>$ 狹形照 一 度

アさे の

于 地 帛 $\stackrel{9 Q}{\sim} 00$

告峽には本分

二 $儿$ 力方束

二なてイ䊀經

○北ザ バ-

$\bigcirc \rightarrow^{\circ}$ 東 、 $>^{\circ}$ 四

米チにウア二

ジェオイ島度

工レッルとよ

I坐フへ其

ド島エル境同

九ゾてネム界一

見、焉灣 ラ 明五

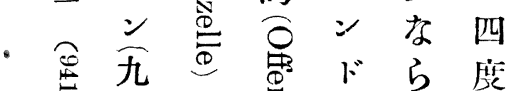

九

ををにずに

$\bigcirc$ 作南屬兩互

米る、束世者 生

歲

出

즈

キンて 本ク ゴ

エ 、> 岛 輸 等

I、リ並出の

タフドに 額 耕

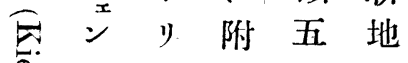

可 七 近 二 亖

に \begin{tabular}{lllll}
$\mathbb{E}$ & ウ & 六 & 萬 \\
\hline & 1 & 昂 & 餘
\end{tabular}



て

政巨, 來 $、$ 力

所ヌム港ル小

心石に $に$ 間束

在公、し二b

九 地芯 フ 船九土

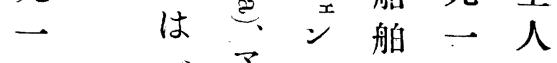

三 バマッ司は二は

年学辛离八年コ

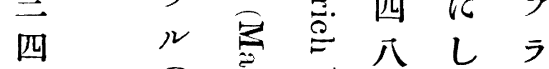



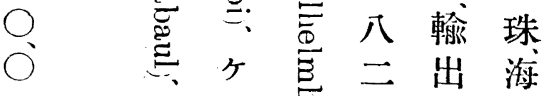

○ に I离吨頓の 參

○しウ $\underset{E}{E}$ と 等

$\checkmark て ィ へ し$ 部を

ル同ンルては交

ク所グバ其 コ易

队河】主プす

政は 要

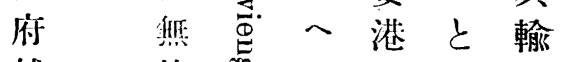

補線夻、は娄 





とピはは午溫は户 、北長 $○$ ×佛七 な⿻一八北前は熱燐 $ト$, 西軸 $\bigcirc$ ク 領 $\bigcirc$ る。六 プ西十一带鈸ミ、にに $\bigcirc$ の米等 來一ア季時月海をラ 潵沿本ン火等 马. 六岛候!攝洋以り!在と方ブ山の

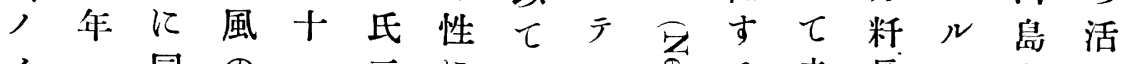
イマ同の一二に著、导る走長グあ火

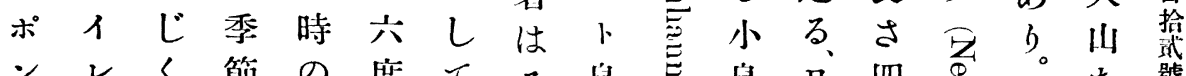

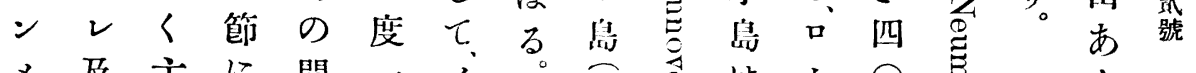
メ及主に閏立;



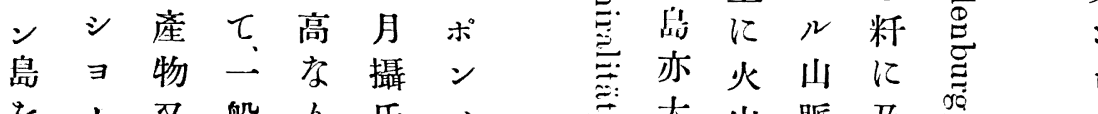


二テ同に五二ル は岛岩こび島

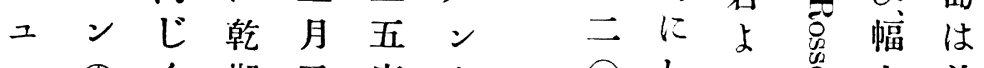
1のく期又度量 ブ 爽さとは二の リ航ブす六最 テをラ。月高ル ン最綿少本バ

\section{要初珦向均 !}

自と琲十攝



苞立么 月 三 1

定等

島四に

$\zeta \equiv \iota$ ま 三ェ

命 年 $\tau$

名皮

七度

せ ス 等

南七悉

$\bigcirc$ ᄂ b $\stackrel{\oplus}{=}$ 七前

○年成と者

○一る稱二の

平 四

有 0

䊀 $\bigcirc$

乙 四束

北 穊 に

あ 本

西にあ

b方

附 粍

近あ

に b

に $し b$

散 ザ

東最宫

在 $ン$

貿低蒂方卜

延 $\tau \tau$.

び南 北

$\tau$ 端に

シ 稍彎

b. $\rightarrow$ Q

易 本 导:

二ン栽

風均

八來培

季氏於

るウ

工廣曲

小

ラくせ

八 3 獎

節 $\rightarrow \tau$

四二勵

に九 三

年七世

し八年

獨 $\bigcirc 5$ て劣間

逸○る。

雨 b.の

帛于

1二る

s

P

二五炏

ッ | 長

中虫岕 $\bigcirc$ る

ッ五标

ン总市市に

ヂ

$\begin{array}{lll}\overparen{2} & \text { あ } & \text { に } \\ \frac{0}{5} & b & L\end{array}$

ン

島

跑

亦

火

山

島

1 递

星 又

害出 $\tau$

少杂

本

岛总 北 方 方 に 
